\title{
Density-dependent seed predation in Attalea geraensis Barb. Rodr. (Arecaceae) caused by bruchid beetles in the Brazilian Cerrado
}

\author{
J. Ragusa-Netto ${ }^{a *}$ \\ aDepartamento de Ciências Naturais, Universidade Federal de Mato Grosso do Sul - UFMS, Campus Três Lagoas, \\ Avenida Ranulpho Marques Leal, 3484, CP 210, CEP 79610-100, Três Lagoas, MS, Brasil \\ *e-mail: jragusanetto@yahoo.com
}

Received: July 28, 2017 - Accepted: February 19, 2018 - Distributed: November 30, 2019

(With 2 figures)

\begin{abstract}
Palms are an important component of Neotropical communities as they are often diverse and abundant. In some areas, palms occur in high density and act as limiting factor in tree recruitment by limiting tree seedling and sapling abundance. In this study, I evaluated the intensity of seed mortality caused by insects in Attalea geraensis, in a large area of preserved Cerrado (Serra do Cabral, MG, Brazil) during wet season when both A. geraensis fruits and bruchid beetles were abundant. I collected a total of 63 infructescences which had from 3 fruits and 7 seeds to 82 fruits and 251 seeds. Endocarps had from 1 to 6 seeds. Seed mortality per infructescence due to beetles (Pachymerus cardo) was intense, and increases positively and disproportionally according to seed number per infructescence. Besides that, average proportions of seeds preyed upon by insects were consistently high $(>0.83)$, irrespective of seed number per endocarp. Positive density-dependent seed mortality caused by specialized natural enemies has been assumed to promote species rarity, an important feature of species coexistence in Neotropical forests. Then, the intense seed mortality documented in this study suggests that seed predators may contribute to the richness and diversity of plant species in the Cerrado, the richest and most endangered savanna in the world.
\end{abstract}

Keywords: fruiting, herbivory, Palmae, plant-animal interaction, seed mortality.

\section{Predação dependente da densidade em sementes de Attalea geraensis Barb. Rodr. (Arecaceae), causada por besouros no Cerrado brasileiro}

\section{Resumo}

Devido à abundância e diversidade, as palmeiras são um componente importante das comunidades neotropicais. Em algumas áreas as palmeiras ocorrem em elevada densidade, tornando-se um fator limitante ao recrutamento de árvores, por restringir a abundância de plântulas e árvores jovens. Neste estudo, avaliei a intensidade de mortalidade das sementes de Attalea geraensis, causada por insetos, em uma grande área preservada de Cerrado (Serra do Cabral, MG, Brasil), durante a estação chuvosa, quando frutos de $A$. geraensis e besouros predadores de sementes eram abundantes. Coletei um total de 63 infrutescências que tinham de 3 frutos e 7 sementes a 82 frutos e 251 sementes. Os endocarpos tinham de 1 a 6 sementes. Nas infrutescências a mortalidade das sementes causada por besouros (Pachymerus cardo) foi intensa e aumentou positiva e desproporcionalmente conforme o número de sementes por infrutescência. Além disso, independentemente do número de sementes por endocarpo, as proporções médias de sementes predadas por endocarpo foram consistentemente altas $(>0,83)$. A mortalidade densidade dependente positiva de sementes causada por inimigos naturais especializados é assumida como uma das principais causas da raridade das espécies vegetais, um fator importante para coexistência de espécies nas florestas neotropicais. Portanto, a intensa mortalidade de sementes documentada neste estudo sugere que predadores de sementes podem contribuir para a riqueza e diversidade de espécies de plantas no Cerrado, a savana mais rica e ameaçada do mundo.

Palavras-chave: frutificação, herbivoria, Palmae, interação animal-planta, mortalidade de sementes.

\section{Introduction}

In the Neotropics, palms are an important component of plant communities from arid areas to rainforests due to local or regional patterns of abundance and diversity
(Svenning, 2001). In fact, palms may be the dominant plants in a variety of habitat types from poorly drained or flooded areas to savannas (Henderson, 2002). Moreover, 
in some habitats palms occur in high densities and may act as a filter in tree recruitment, limiting tree seedling and sapling abundance and, potentially, influencing the composition of tree species (Aguiar and Tabarelli, 2009; Andreazzi et al., 2012). Unlike other vertebrate-dispersed plants, many palm species present a low fruiting synchrony (Peres, 2000). As a result, in some sites when fleshy fruits decline, palms are among the few food resources available to support frugivorous community biomass (van Schaik et al., 1993). Indeed, palm fruits and seeds include high nutritional content, which attracts a wide spectrum of either seed dispersers or predators (Zona and Henderson, 1989).

Seed predation is an important cause of mortality throughout the life cycle of plants and one of the main processes underlying plant recruitment patterns (Janzen, 1970; Connell, 1971; Harms et al., 2000; Terborgh, 2012). The proximity to the parent plant as well as the high density of seeds near it attracts seed consumers, which ultimately reduces seedling recruitment close to the mother tree, whereas seeds that are dispersed further away from parents have an increased chance of survival (Janzen, 1970; Connell, 1971; Howe et al., 1985). The intense mortality near the parent plant is usually a consequence of host-specific predators or pathogens (Bagchi et al., 2010; Terborgh, 2012). Invertebrate seed predators such as insects tend to be host-specific, which exhibit higher population densities and prolonged residence times at each plant (Janzen, 1970; Visser et al., 2011). Moreover, they are often density or distance-responsive seed predators that generate patterns conforming to the Janzen-Connell model, whereas vertebrates, typically mobile and generalist seed consumers, generate other kinds of patterns (Tuomisto et al., 2004; Terborgh, 2012). Among insects, bruchids and curculionid beetles use seeds for the development of their young (Crawley, 1992). Particularly, bruchid beetles rely on palm seeds during a large part of their life cycle (Johnson et al., 1995). These beetles are well known for damaging high percentages of all fruits found beneath the parent palm (Terborgh, 2012).

Attalea Kunth is a Neotropical genus with 38 species dispersed from forests to savanna-like habitats (Henderson, 2002). Most species are canopy trees, although short-stemmed species are also found in forest understory or savannas (Lorenzi et al., 2010). These palms generally produce large, one-to-six-seeded fruits (Lorenzi et al., 2010), often dispersed by vertebrates (Forget et al., 1994; Pimentel and Tabarelli, 2004), while bruchid beetles may cause severe seed mortality on undispersed fruits (Wright, 1983; Henderson, 2002). Attalea geraensis Barb. Rodr. is a common palm in the Brazilian Cerrado; adult plants have a short subterranean stem which seldom reaches more than $1 \mathrm{~m}$ tall (Lorenzi et al., 2010). Infructescences are produced all year round and include from few to dozens of fruits, which mature at ground level; they have 1-4 seeds attractive to insects and vertebrates (Bonjorne de Almeida and Galetti, 2007; Lorenzi et al., 2010).

Evaluations on the intensity of seed mortality caused by insects have demonstrated that positive density-dependent seed predation may not be a rule among palms (Visser et al., 2011; Dracxler et al., 2011). Besides that, in the absence of intense seed predation, Attalea species may experience population increase becoming dominant plants, while local plant richness decline in the community (Aguiar and Tabarelli, 2009; Andreazzi et al., 2012). As mentioned above, bruchid beetles may strongly damage Attalea fruit crops, mainly in the wet season when bruchid beetles are actively breeding (Wright, 1990). To improve evaluations on the effect of biotic factors affecting plant populations from Cerrado (Vaz Ferreira et al., 2011), in this study I assessed the intensity of seed mortality caused by insects in Attalea geraensis from a large area of preserved Cerrado (Serra do Cabral, MG, Brazil). This evaluation was done during the wet season when $A$. geraensis fruits and bruchid beetles are often abundant (Wright, 1990; Bonjorne de Almeida and Galetti, 2007). Given that understanding the effect of seed predators on fruit crops has important management and conservation implications, this is valid for A. geraensis, which fruits and seeds may be important sources for biofuel production (Nass et al., 2007; Lorenzi et al., 2010). Besides that, this palm is declining together with the Cerrado (Carvalho et al., 2009).

\section{Methods}

\subsection{Study site}

This study was developed in January 2016 in the Cerrado (Brazilian savanna) of Parque Estadual de Serra do Cabral, in the municipalities of Buenópolis and João Felício (State of Minas Gerais, Brazil: $17^{\circ} 43^{\prime} \mathrm{S}$ and $44^{\circ} 14^{\prime} \mathrm{W}$; altitude $1200 \mathrm{~m}$ ) including an area of 22,500 ha. Mean annual temperature is $20 \cdot 1^{\circ} \mathrm{C}$. Higher mean temperature is recorded in January and February $\left( \pm 24.5^{\circ} \mathrm{C}\right)$. In June and July mean temperature is $17.3^{\circ} \mathrm{C}$. During June-July, the day-break temperature often drops to $5^{\circ} \mathrm{C}$ or less and frost may occur. Mean annual rainfall is around $1200 \mathrm{~mm}$, with 700-800 mm between October and March. Hence, there is a wet-hot season extending from October to March and a dry-cold season from April to September. The Cerrado vegetation consists mainly of a continuous ground layer dominated by grasses, and a woody layer varying in ground cover from 30 to $70 \%$ of trees of 2-8 m high (Ribeiro and Walter et al., 1998). Characteristic trees include Caryocar brasiliense Cambess., Pouteria torta (Mart.) Radlk., Qualea grandiflora Mart., Q. parviflora Mart., Hymenaea stigonocarpa Mart. ex Hayne, Annona crassiflora Mart., Anadenanthera falcata (Benth.) Speg., Hancornia speciosa Gomes, Stryphnodendron adstringens (Mat.) Coville, and Curatella americana L. Also, common palm species are Syagrus evansiana Noblick, Allagoptera campestris (Mart.) Kuntze, Mauritia flexuosa L.f., and Attalea geraensis (pers. observ.).

\subsection{Study species}

Attalea gearensis Barb.Rodr. occurs in the Cerrado of Brazilian states of São Paulo, Minas Gerais, Mato Grosso do Sul, Goiás and Bahia (Lorenzi et al., 2010). It is present 
both in preserved and disturbed Cerrado, as well as in open areas, such as pastures. In some sites, either preserved or human-modified, A. geraensis may form nearly pure stands (Henderson, 2002). Consequently, sometimes it has been regarded as a pasture invader (Lorenzi et al., 2010). The aerial portion is composed of the crown with 2-11 leaves 1.4-2.2 $\mathrm{m}$ long, in which leaflets are regularly arranged in the same plane exhibiting brown scales on the lower surface. The palms start to produce fruits with 3-5 years old (Lorenzi et al., 2010). Fruiting occurs all year round and seeds are dispersed by rodents (Bonjorne de Almeida and Galetti, 2007). Mature individuals often produce one infructescence per year, with 1-60 fruits each (Henderson, 2002). Fruits are globular drupes measuring $3-7 \mathrm{~cm}$ in length, and $2-5 \mathrm{~cm}$ in diameter; these drupes have a hard, indehiscent endocarp surrounding 1-3 seeds, although 4-6 seeds may be present; pyrenes (i.e., the seeds contained in stony endocarps) are globular with a coconut-like endosperm (Lorenzi et al., 2010). At the study site, fresh fruits of Attalea geraensis had (mean $\pm \mathrm{sd}$ ) $4.7 \pm 0.9 \mathrm{~cm}$ length and $3.9 \pm 0.4 \mathrm{~cm}$ width $(\mathrm{n}=30)$, the exocarp is thin $(1.5 \mathrm{~mm})$ and the mesocarp is pulpy $(2-4 \mathrm{~mm}$ thick) and edible. In the Parque Estadual da Serra do Cabral, mammal species such as Tapirus terrestris (Linnaeus, 1758), Dasyprocta sp. (Illiger, 1811), Kerodon rupestris (Wied-Neuwied, 1820), Thrichomys apereoides (Lund, 1839), and Clyomys sp. (Thomas, 1916), are common (Marinho-Filho et al., 2002), and may play the role of seed dispersers of $A$. geraensis seeds. With the exception of T. terrestris, and in addition to Cuniculus paca (Linnaeus, 1776), all other species may also prey on A. geraensis seeds.

\subsection{Infructescences collection}

I searched for fruiting palms in the first week of January 2016. Then, I established a 3-km-long transect and all adults present within a 5-m radius on both sides of transect were inspected for the presence of mature infructescences. Sampled palms were spaced by at least $30 \mathrm{~m}$ from each other, a distance that roughly corresponds to the usual spacing among $A$. geraensis clumps in the area. In addition, palms sampled were at least $5 \mathrm{~m}$ away from any other conspecific adult, in order to avoid collecting fruits from other individuals. All sampled individuals were in flat topography because in slopes the fruits roll away. Along the sampling transect, all palm individuals which fulfilled these requirements where sampled. To assure the collection of recently produced fruits, and to avoid those from past fruiting episodes (endocarps that remain on the ground take years to decompose), I only collected fruits from infructescences which were attached to the palm, and $5-10 \%$ of fruits were yet attached to the raquis, besides those found within $1 \mathrm{~m}$ radius around the infructescence of the A. geraensis sampled. A $1 \mathrm{~m}$ radius was used because as A. geraensis has a subterranean stem, mature infructescences lay on the ground and therefore most fruits are dropped within this distance. Besides that, the collection of fruits close to infructescences suggested minimal or no signals of manipulation by vertebrates as nuts generally were very close to each other. Also, fruits still had exocarp, although with signs of advanced maturation, in which they exhibit dark greyish brown color, and smell of pulp fermentation, which is assumed to attract bruchid females (Wright, 1983). Collected fruits from a given infructescence were placed on drying paper and stored in properly labeled plastic bags. Once back in the laboratory, endocarps were opened for an examination of the seed condition and were classed in two categories: a) intact, for no sign of mortality agent; b) preyed upon by insects, when endocarps presented a larva or an adult inside them, or presented entry or exit holes. Bruchid specimens collected inside pyrenes were identified by specialists, and specimens were deposited in the collection of the Laboratório de Invertebrados, UFMS-Campus Três Lagoas.

\subsection{Analyzes}

To assess seed predation intensity caused by the initial number of seeds per infrutescence, I assessed the relationship $\left(\mathrm{I}=\mathrm{aR}^{\mathrm{b}}\right)$ between the initial number $(\mathrm{I})$ and the number of predated seeds (R). Then, I analyzed the initial-predated relationship by linear regression of $\log$ transformed values of $\mathrm{I}+1$ and $\mathrm{R}+1$ (power law equation), to normalize residuals. Indeed, with: $\log (\mathrm{y}+1)=\mathrm{a}+b \log (\mathrm{x}+1)$, I assessed density-dependent effect, where $\mathrm{x}$ is the initial number of seeds at a given infrutescence and $y$ is the respective number of predated seeds; $b$ is the slope representing the rate in which the number of predated seeds increases in relation to the initial number of seeds. The constant $b$ may be equal, minor or higher than 1 . Higher values imply in positive density-dependence, while $b=1$, independence. Values of less than 1 imply in negative density-dependence because per seed probability of predation is inversely related to seed density. Seed mortality intensity was assessed for each infructescence by using the number of attacked seeds in a given infructescence and the total number of seeds in that same infructescence. Bruchid larvae complete their development inside a single seed regardless of the number of seeds per endocarp (Wright, 1990). Therefore, I considered seed predation as independent of the number of seeds present in each endocarp (see results below). Taking into account seed predation only at the level of endocarps would be an underestimate of seed predation. Moreover, in this study I used the infructescence as the experimental unit. In this sense I took a single value of seeds predated for each replicate of each infructescence and used these values for the analyses. To improve the evaluation on the occurrence of density-dependence, the number of predated seeds according to observed $b$ value was confronted (paired $t$-test) with the predicted number if $b=1$ (Harms et al., 2000). Finally, as fruits had from one to six seeds, I compared mean proportions of seed predation per fruit by analysis of variance (ANOVA). The proportions of predated seeds per endocarp were arc-sine square-root transformed before analysis in order to approach normality and reduce heteroscedasticity. 


\section{Results}

I collected 63 infructescences that had from 3 fruits and 7 seeds to 82 fruits and 251 seeds. On average (mean \pm se) infructescences had $23.21 \pm 2.01$ fruits and $59.60 \pm 5.67$ seeds. Attalea geraensis endocarps had 1-6 seeds, so that 313 were one-seeded endocarps, 470 were two-seeded, 388 three-seeded, 220 four-seeded, 76 five-seeded, and only 13 six-seeded endocarps. Despite variations in the number of seeds per endocarp, the number of fruits and seeds per infructescence had a high and significant correlation $(r=0.90, p=0.0001, n=63)$. Seed mortality per infructescence due to insects ranged from 0 to $100 \%$. Only one infructescence with 16 fruits and 40 seeds had no seed predated, while in 14 infructescences seed mortality was $100 \%$. These infructescences had from 6 fruits and 11 seeds to 53 fruits and 193 seeds (average: $23.43 \pm 3.88$ fruits, and $51.21 \pm 12.08$ seeds). Besides that, 54 infructescences had $>50 \%$ of seeds consumed by insects, while only 9 had $<50 \%$ of seeds killed by these predators. In the last case, they had $13.22 \pm 3.88$ fruits, and $26.90 \pm 5.88$ seeds $(29.11 \pm 6.11 \%$ killed by insects). As general average, $81.40 \pm 3.13 \%$ of seeds per infructescence were predated. I recorded a total of 2159 beetle larvae, as well as 252 individuals of Pachymerus cardo (Fahraeus, 1839) (Bruchidae) inside pyrenes, in addition to 823 empty pyrenes each one with only one exit hole. The proportion of seeds predated per endocarp also ranged from 0.00 to 1.00 . In the one-seeded endocarps $(n=313)$, on average $0.85 \pm 0.02$ seeds were killed by insects. In the two-seeded endocarps the proportion was $0.84 \pm 0.01(\mathrm{n}=470)$, in the three-seeded ones $0.87 \pm$ $0.01(n=388)$, in the four seeded $0.87 \pm 0.02(n=220)$. Finally, grouping five and six-seeded endocarps, the proportion of seeds consumed by insects was $0.92 \pm 0.02$ $(\mathrm{n}=89)$. No significant difference emerged among those proportions $(\mathrm{F}=1.06, \mathrm{p}=0.380$, Figure 1$)$. However, seed mortality due to insects varied intensely according to infructescence size. The observed slope value of the log-log regression between the initial-predated number of seeds was $b=1.29$, which was significantly different from $b=0\left(t=12.99, r^{2}=0.73, \mathrm{p}<0.0001\right)$, and significantly higher than $b=1(\mathrm{t}=3.90, P<0.0002, \mathrm{n}=63$, Figure 2$)$. Hence, the intensity of seed mortality positively and disproportionally increases according to the number of seeds per infructescence.

\section{Discussion}

Previous studies on Attalea palms found percentages ranging from 35 to $100 \%$ of seed mortality due to bruchid beetles infestation (Janzen, 1971; Quiroga-Castro and Roldán, 2001; Pimentel and Tabarelli, 2004; Rios and Pacheco, 2006). Then, the extent of seed mortality caused by insects, in this study, was among the highest ever recorded for Attalea palms. Besides that, in contrast to previous studies (Janzen, 1971; Wright, 1983; Henderson, 2002), and in accordance to Pimentel and Tabarelli (2004), my results also pointed out that endocarp infestation by

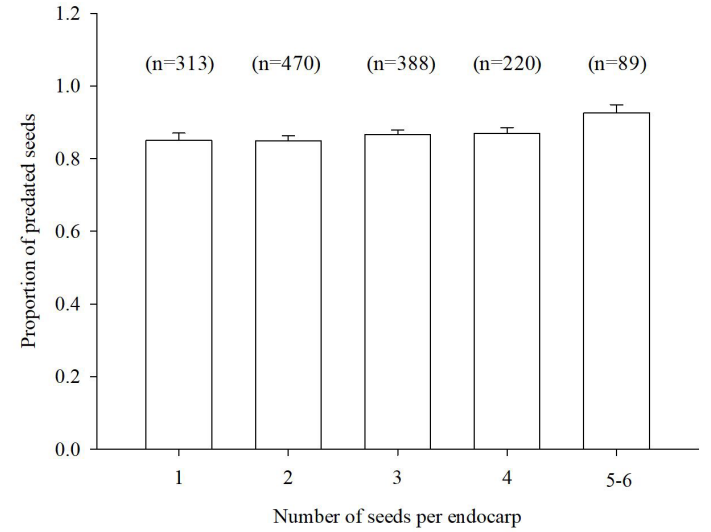

Figure 1. Mean ( \pm se) proportions of seed predation in relation to the number of seeds per endocarp of Attalea geraensis (between parentheses the number of endocarps; Parque Estadual da Serra do Cabral, MG, Brazil, January 2016).

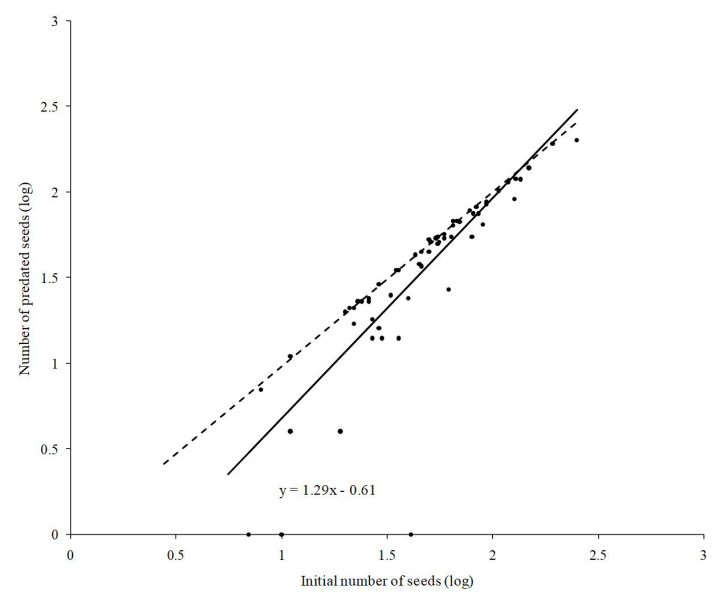

Figure 2. The relationship between the initial number and the number of Attalea geraensis seeds predated per infructescence. Continuous line describes the log-log regression indicating positive density-dependence. Dashed line describes the expected relationship in the absence of density-dependence (linear regressions of log transformed values is also provided; see text for further details; Parque Estadual da Serra do Cabral, MG, Brazil, January 2016).

bruchids may occur even in the absence of exocarp removal by vertebrates. Indeed, the proportion of seeds alive after an attack will be minimized by insects that deposit their eggs uniformly among seeds. Taking this into account, insects that indiscriminately lay eggs on any available seed will not be compelled to leave the concentration of seeds in the immediate vicinity of the parent plant causing increased seed mortality (Wright, 1983). Moreover, bruchid beetles population sizes are affected by factors as palm phenology, reproductive output and environmental conditions, which may cause highly variable spatial and temporal patterns of 
beetle abundance (Wright, 1990). As they are short-lived host specialists with high reproductive rates (Janzen, 1970), bruchids often impose severe damage to aggregations of seeds in the proximity of adult trees (Wright, 1990; Terborgh, 2012).

Attalea endocarps are susceptible to infestation while exocarp is putrefying and until the smell and taste of pulp fermentation is gone from their surface, which attracts bruchid females (Wright, 1983). Then, bruchid beetles, apparently, were able to detect differences in seed densities at infructescence level. This also may account for the higher bruchid infestation in larger infructescences inspected for the presence of insects in this study (Wilson and Janzen, 1972; Pimentel and Tabarelli, 2004). In fact, seed predators actively forage for seed patches, and when faced with an adequate seed source, they can respond functionally or numerically. Functional response is related to the proportion of prey consumed by an individual predator, while a numerical response is related to changes in the density of predators (Holling, 1959). In principle, an intense attack might not be a consequence of only a numerical response, as adult beetle emergence is likely to be proportional to host density at given area (Visser et al., 2011). The intense seed mortality in larger infructescences might also reflect an enhanced breeding effort, as those infructescences should stimulate female beetles to increase oviposition on endocarps available (Wilson and Janzen, 1972; Wright, 1983; Pimentel and Tabarelli, 2004). Indeed, the number of seeds per endocarp had no effect on the proportion of seeds preyed upon by insects in A. geraensis. As Attalea endocarps attacked by bruchid beetles always had only one beetle larvae per seed, the absence of a relationship between seed number and the proportion of seeds killed per endocarp reinforces the potential occurrence of a functional response by beetles to local availability of seeds. Additionally, the combination of factors as large fruit patches, low mobility of bruchid beetles and summer temperatures, may favor the occurrence of a functional response to seed density (Visser et al., 2011). Importantly, where a tree species is common and when seeds are plentiful, seed dispersers may be swamped (Hampe, 2008; Ragusa-Netto, 2016), consequently reducing seed dispersal (Klinger and Rejmánek, 2009; Jansen et al., 2014). The consequence is the exposition of an increased number of seeds for prolonged periods to bruchid attack. Therefore, the infestation of A. geraensis seeds by beetles might be a combination of functional and numerical response (Visser et al., 2011). The enhanced number of seeds killed by bruchids in larger infructescence is consistent with the expectation that specialist predators may exhibit a disproportional response to host density causing positive density-dependent seed mortality (Terborgh, 2012).

Attack by specialized pests is expected to increase disproportionately with increasing host plant abundance (Swamy and Terborgh, 2010; Bagchi et al., 2010), leading to negative density-dependent recruitment of plant species (Harms et al., 2000), which favors species rarity, a major trait for species coexistence (Chesson, 2000). In this respect, pathogens and insects are widely believed to be important agents for the maintenance of plant species diversity in tropical forests (Terborgh, 2012). The relationship between palms and its agents of seed mortality may affect palm demography and spatial distribution promoting coexistence with diverse plant species (Wright, 2002; Terborgh, 2012). In this study, despite the fact that seed survival was proportionally higher in smaller than in larger infructescences, the final number of surviving seeds was often moderate, so that at least some seeds might be dispersed favoring recruitment of $A$. geraensis. Indeed, the strength of seed predation may vary from patch to patch (e.g. from plant to plant or from fruit to fruit) within a plant population, which is also an important source of variation in predation levels among plants at a local scale (Kolb et al., 2007). Thus, in pristine areas plant population size may continue enhanced even under high levels of seed predation (Turnbull et al., 2000; Kolb et al., 2007). In the absence of severe seed predation by beetles, Attalea palms may experience pronounced populational increase, resulting in monodominant stands (Henderson, 2002). Such disruption has been commonly reported in anthropized areas such as pastures (Lorenzi et al., 2010) or fragments' edges (Aguiar and Tabarelli, 2009). In fact, monospecific palm stands may be both a consequence and a cause of biodiversity impoverishment (Henderson, 2002). The early studies on density-dependent seed mortality (Janzen, 1970; Connell, 1971) pointed out the importance of studies on seed-seedling mortality for the maintenance of diversity on local spatial scales in tropical forests (Wright, 2002). In the case of Cerrado, abiotic factors (fire, soil chemistry, and climate) have been assumed as major structuring factors on plant communities (Hoffmann and Moreira, 2002; Cruz Ruggiero et al., 2002). On the other hand, biotic factors might play a minor role on the demography of plants in this rich and diverse savanna (Gardner, 2006). In spite of that, investigations focusing on the effect of biotic factors in limiting Cerrado plant population growth need more and continuous efforts, which may improve our knowledge on the importance of these factors as some studies have been shown (Francisco et al., 2008; Ragusa-Netto, 2011, 2014, 2016, 2017; Vaz Ferreira et al. 2011).

\section{Acknowledgements}

The author is grateful to an anonymous reviewer for the constructive comments on an earlier version of this study. Márcia Grando Ragusa kindly provided field assistance. Financial support was provided by Conselho Nacional de Desenvolvimento Científico e Tecnológico (CNPq).

\section{References}

AGUIAR, A.V. and TABARELLI, M., 2009. Edge effects and seedling bank depletion: the role played by the early successional palm Attalea oleifera (Arecaceae) in the Atlantic Forest. Biotropica, vol. 42, no. 2, pp. 158-166. http://dx.doi.org/10.1111/j.17447429.2009.00555.x. 
ANDREAZZI, C.S., PIMENTA, C.S., PIRES, A.S., FERNANDEZ, F.A.S., OLIVEIRA-SANTOS, L.G. and MENEZES, J.F.S., 2012. Increased productivity and reduced seed predation favor a large-seeded palm in small Atlantic Forest fragments. Biotropica, vol. 44, no. 2, pp. 237-245. http://dx.doi.org/10.1111/j.17447429.2011.00782.x.

BAGCHI, R., SWINFIELD, T., GALLERY, R.E., LEWIS, O.T., GRIPENBERG, S., NARAYAN, L. and FRECKLETON, R.P., 2010. Testing the Janzen-Connell mechanism: pathogens cause overcompensating density dependence in a tropical tree. Ecology Letters, vol. 13, no. 10, pp. 1262-1269. http://dx.doi. org/10.1111/j.1461-0248.2010.01520.x. PMid:20718845.

BONJORNE DE ALMEIDA, L. and GALETTI, M., 2007. Seed dispersal and spatial distribution of Attalea geraensis (Arecaceae) in two remnants of Cerrado in Southeastern Brazil. Acta Oecologica, vol. 32, no. 2, pp. 180-187. http://dx.doi. org/10.1016/j.actao.2007.04.001.

CARVAlHo, F.M.V., DEMARCO, P.J. and FERREIRA, L.G., 2009. The Cerrado into-pieces: Habitat fragmentation as a function of landscape use in the savannas of Central Brazil. Biological Conservation, vol. 142, no. 7, pp. 1392-1403. http:// dx.doi.org/10.1016/j.biocon.2009.01.031.

CHESSON, P., 2000. Mechanisms of maintenance of species diversity. Annual Review of Ecology and Systematics, vol. 31, no. 1, pp. 343-366. http://dx.doi.org/10.1146/annurev.ecolsys.31.1.343.

CONNELL, J.H., 1971. On the role of natural enemies in preventing competitive exclusion in some marine animals and in rain forest trees. In: P.J. Den Boer, D. Gradwell, eds. Dynamics of populations. Wageningen: Centre for Agricultural Publishing and Documentation, pp. 298-310.

CRAWLEY, M.J. 1992. Seed predators and plant population dynamics. In: Fenner M. ed. The ecology of regeneration in plant communities. Wallingford, Oxon: CAB International, pp. 157-192

CRUZ RUGGIERO, P.G., BATALHA, M.A., PIVELLO, V.R. and MEIRELLES, S.T., 2002. Soil-vegetation relationships in cerrado (Brazilian savanna) and semideciduous forest, southeastern Brazil. Plant Ecology, vol. 160, no. 1, pp. 1-16. http://dx.doi. org/10.1023/A:1015819219386.

DRACXLER, C., PIRES, A.S. and FERNANDEZ, F.A.S., 2011. Invertebrate seed predators are not all the same: Seed predation by bruchine and scolytine beetles affects palm recruitment in different ways. Biotropica, vol. 43, no. 1, pp. 8-11. http://dx.doi. org/10.1111/j.1744-7429.2010.00723.x.

FORGET, P.M., MUÑOZ, E. and LEIGH, E.G.J.R., 1994. Predation by rodents and bruchid beetles on seeds of Scheelea palms on Barro Colorado Island, Panama. Biotropica, vol. 26, no. 4, pp. 420-426. http://dx.doi.org/10.2307/2389236.

FRANCISCO, M.R., LUNARDI, V.O., GUIMARÃES JUNIOR, P.R. and GALETTI, M., 2008. Factors affecting seed predation of Eriotheca gracilipes (Bombacaceae) by parakeets in a cerrado fragment. Acta Oecologica, vol. 33, no. 2, pp. 240-245. http:// dx.doi.org/10.1016/j.actao.2007.11.002.

GARDNER, T.A., 2006. Tree-grass coexistence in the Brazilian cerrado: demographic consequences of environmental instability. Journal of Biogeography, vol. 33, no. 3, pp. 448-463. http://dx.doi. org $/ 10.1111 / \mathrm{j} .1365-2699.2005 .01420 . x$.

HAMPE, A., 2008. Fruit tracking, frugivore satiation, and their consequences for seed dispersal. Oecologia, vol. 156, no. 1, pp. 137-145. http://dx.doi.org/10.1007/s00442-008-0979-0. PMid:18270742.

HARMS, K.E., WRIGHT, S.J., CALDERON, O., HERNANDEZ, A. and HERRE, E.A., 2000. Pervasive density-dependent recruitment enhances seedling diversity in a tropical forest. Nature, vol. 404, no. 6777, pp. 493-495. http://dx.doi.org/10.1038/35006630. PMid:10761916.

HENDERSON, A. 2002. Evolution and ecology of palms. New York: The New York Botanical Garden Press, 198 p.

HOFFMANN, W.A. and MOREIRA, A.G. 2002. The role of fire in population dynamics of woody plants. In: P.S. Oliveira, R.J. Marquis, eds. The cerrados of Brazil: ecology and natural history of a neotropical savanna. New York: Columbia University Press, pp. 159-177. http://dx.doi.org/10.7312/oliv12042-008.

HOLLING, C.S., 1959. The components of predation as revealed by a study of small mammal predation of the European Pine Sawfly. Canadian Entomologist, vol. 91, no. 05, pp. 293-320. http://dx.doi.org/10.4039/Ent91293-5.

HOWE, H.F., SCHUPP, E.W. and WESTLEY, L.C., 1985. Early consequences of seed dispersal for a neotropical tree (Virola surinamensis). Ecology, vol. 66, no. 3, pp. 781-791. http://dx.doi. org/10.2307/1940539.

JANSEN, P.A., VISSER, M.D., JOSEPH WRIGHT, S., RUTTEN, G. and MULLER-LANDAU, H.C., 2014. Negative density dependence of seed dispersal and seedling recruitment in a Neotropical palm. Ecology Letters, vol. 17, no. 9, pp. 1111-1120. http://dx.doi.org/10.1111/ele.12317. PMid:25039608.

JANZEN, D.H., 1970. Herbivores and the number of tree species in tropical forests. American Naturalist, vol. 104, no. 940, pp. 501-528. http://dx.doi.org/10.1086/282687.

JANZEN, D.H., 1971. The fate of Scheellea rostrata fruits beneath the parent tree: Predispersal attack by bruchids. Principes, vol. 15, pp. 89-101.

JOHNSON, C.D., ZONA, S. and NILSSON, J.A., 1995. Bruchid beetles and palm seeds: recorded relationships. Principes, vol. 39, pp. 25-35.

KLINGER, R. and REJMÁNEK, M., 2009. The numerical and functional responses of a granivorous rodent and the fate of Neotropical tree seeds. Ecology, vol. 90, no. 6, pp. 1549-1563. http://dx.doi.org/10.1890/07-2146.1. PMid:19569370.

KOLB, A., EHRLÉN, J. and ERIKSSON, O., 2007. Ecological and evolutionary consequences of spatial and temporal variation in pre-dispersal seed predation. Perspectives in Plant Ecology, Evolution and Systematics, vol. 9, no. 2, pp. 79-100. http://dx.doi. org/10.1016/j.ppees.2007.09.001.

LORENZI, H., NOBLICK, L., KAHA, F. and FERREIRA, E. 2010. Flora Brasileira: Arecaceae (Palms). Nova Odessa: Instituto Plantarium. 384 p.

MARINHO-FILHO, J., RODRIGUES, F.H.G. and JUAREZ, K.M. 2002. The Cerrado mammals: diversity, ecology and natural history. In: P.S. OLIVERIA \& R.J. MARQUIS, eds. The cerrados of Brazil: ecology and natural history of a neotropical savanna. New York: Columbia University Press, pp. 266-286. http://dx.doi. org/10.7312/oliv12042-013.

NASS, L.L., PEREIRA, P.A.A. and ELLIS, D., 2007. Biofuels in Brazil: an overview. Crop Science, vol. 47, no. 6, pp. 2228-2237. http://dx.doi.org/10.2135/cropsci2007.03.0166. 
PERES, C.A., 2000. Identifying keystone plant resources in tropical forests: the case of gums from Parkia pods. Journal of Tropical Ecology, vol. 16, no. 2, pp. 287-317. http://dx.doi. org/10.1017/S0266467400001413.

PIMENTEL, D.S. and TABARELLI, M., 2004. Seed dispersal of the palm Attalea oleifera in a remnant of the Brazilian Atlantic Forest. Biotropica, vol. 36, no. 1, pp. 74-84. http://dx.doi. org/10.1111/j.1744-7429.2004.tb00298.x.

QUIROGA-CASTRO, V.D. and ROLDÁN, A.I., 2001. The fate of Attalea phalerata (Palmae) seeds dispersed to a tapir latrine. Biotropica, vol. 33, no. 3, pp. 472-477. http://dx.doi. org/10.1111/j.1744-7429.2001.tb00200.x.

RAGUSA-NETTO, J., 2011. Pre-dispersal seed predation by Blue-and-Yellow Macaw (Ara ararauna, Psittacidae), on fruit crops of the Pequi (Caryocar brasiliense, Caryocariaceae), in the Brazilian cerrado. Ornitologia Neotropical, vol. 22, pp. 329-338.

RAGUSA-NETTO, J., 2014. Crop damage of Eriotheca gracilipes (Bombacaceae) by the Blue-Fronted Amazon (Amazona aestiva, Psittacidae), in the Brazilian Cerrado. Brazilian Journal of Biology = Revista Brasileira de Biologia, vol. 74, no. 4, pp. 837-843. PMid:25627593.

RAGUSA-NETTO, J., 2016. Nut density and removal in Syagrus loefgrenii Glassman (Arecaceae) in the Brazilian Cerrado. Brazilian Journal of Biology $=$ Revista Brasileira de Biologia, vol. 76, pp. 300-309.

RAGUSA-NETTO, J., 2017. Seed removal of Dipteryx alata Vog. (Leguminosae: Faboidae) in the edge and interior of Cerrado. Brazilian Journal of Biology $=$ Revista Brasileira de Biologia, vol. 77, pp. 752-761.

RIBEIRO, J.F. and WALTER, B.M.T. 1998. Fitofisionomias do cerrado. In: S.M. Sano, S.P. Almeida, eds. Cerrado: ambiente e flora. Embrapa, Planaltina, Brazil. pp. 89-166.

RIOS, R.S. and PACHECO, L.F., 2006. The effect of dung and dispersal on post-dispersal seed predation of Attalea phalerata (Arecaceae) by bruchid beetles. Biotropica, vol. 38, no. 6, pp. 778-781. http://dx.doi.org/10.1111/j.1744-7429.2006.00209.x.

SVENNING, J.-C., 2001. On the role of microenvironmental heterogeneity in the ecology and diversification of Neotropical rain-forest palms (Arecaceae). Botanical Review, vol. 67, no. 1, pp. 1-53. http://dx.doi.org/10.1007/BF02857848.

SWAMY, V. and TERBORGH, J., 2010. Distance responsive natural enemies strongly influence seedling establishment patterns of multiple species in an Amazonian rain forest. Journal of Ecology, vol. 98, no. 5, pp. 1096-1107. http://dx.doi.org/10.1111/j.13652745.2010.01686.x

TERBORGH, J., 2012. Enemies maintain hyperdiverse tropical forests. American Naturalist, vol. 179, no. 3, pp. 303-314. http:// dx.doi.org/10.1086/664183. PMid:22322219.

TUOMISTO, H., LOISELLE, B.A. and ROMO, M., 2004. On the density-dependence of seed predation in Dipteryx micrantha, a bat-dispersed rain forest tree. Oecologia, vol. 140, no. 1, pp. 76-85. http://dx.doi.org/10.1007/s00442-004-1502-x. PMid:15148597.

TURNBULL, L.A., CRAWLEY, M.J. and REES, M., 2000. Are plant populations seed-limited? A review of seed sowing experiments. Oikos, vol. 88, no. 2, pp. 225-238. http://dx.doi. org/10.1034/j.1600-0706.2000.880201.x.

VAN SCHAIK, C.P., TERBORGH, J.W. and WRIGHT, S.J., 1993. The phenology of tropical forests, adaptive significance, and consequences for primary consumers. Annual Review of Ecology and Systematics, vol. 24, no. 1, pp. 353-377. http:// dx.doi.org/10.1146/annurev.es.24.110193.002033.

VAZ FERREIRA, A., BRUNA, E.M. and VASCONCELOS, H.L., 2011. Seed predators limit plant recruitment in Neotropical savannas. Oikos, vol. 120, no. 7, pp. 1013-1022. http://dx.doi. org/10.1111/j.1600-0706.2010.19052.x.

VISSER, M.D., MULLER-LANDAU, H.C., WRIGHT, S.J., RUTTEN, G. and JANSEN, P.A., 2011. Tri-trophic interactions affect density dependence of seed fate in a tropical forest palm. Ecology Letters, vol. 14, no. 11, pp. 1093-1100. http://dx.doi. org/10.1111/j.1461-0248.2011.01677.x. PMid:21899693.

WILSON, D.E. and JANZEN, D.H., 1972. Predation on Scheelea palm Seeds by bruchid beetles: seed density and distance from the parental palm. Ecology, vol. 5, no. 5, pp. 954-959. http:// dx.doi.org/10.2307/1934315.

WRIGHT, J.S., 2002. Plant diversity in tropical forests: A review of mechanisms of species coexistence. Oecologia, vol. 130, no. 1, pp. 1-14. http://dx.doi.org/10.1007/s004420100809. PMid:28547014.

WRIGHT, S.J., 1983. The dispersion of eggs by a bruchid beetle among Scheelea palm seeds and the effect of distance to the parent palm. Ecology, vol. 64, no. 5, pp. 1016-1021. http:// dx.doi.org/10.2307/1937808.

WRIGHT, S.J., 1990. Cumulative satiation of a seed predator over the fruiting season of its host. Oikos, vol. 58, no. 3, pp. 272-276. http://dx.doi.org/10.2307/3545217.

ZONA, S. and HENDERSON, A., 1989. A review of animalmediated seed dispersal of palms. Selbyana, vol. 11, pp. 6-21. 